\title{
Pascal: a religião como experiência de contingência e alteridade
}

\author{
Jimmy Sudário Cabral
}

Universidade Federal de Juiz de Fora

\section{Resumo}

O artigo analisa a interpretação de Pascal do conceito de religião e a configuração anárquica do cristianismo presente em sua obra Pensées. À luz de conceitos centrais na obra pascaliana, tais como equivocidade, desproporção e contingência, e do seu diálogo com o pensamento de Descartes e Montaigne, o artigo apresenta a rejeição pascaliana dos conceitos de natureza, interioridade e princípio, fundamentais na elaboração de certo vocabulário filosófico/teológico e místico. Argumentamos que o diálogo de Pascal com o ceticismo e o racionalismo ofereceu uma propedêutica ao seu pensamento religioso e articulou uma gramática filosófico religiosa resistente a a) um vocabulário místico com raízes neoplatônicas, b) uma filosofia panteísta da natureza e c) ao gesto ontoteológico que deu à luz ao que Pascal chamou de deus dos filósofos.

Palavras-chave: Pascal; religião; cristianismo; filosofia; contingência

\section{Pascal: Religion as an Experience of Contingency and Otherness}

\begin{abstract}
This paper analyzes Pascal's Pensées interpretation on religion and the anarchic configuration of Christianity. According to Pascal's work main concepts — such as equivocity, disproportion and contingency — and in his dialogue with Descartes and Montaigne thoughts, the paper presents the pascalienne rejection of the concepts of nature, interiority and principle, fundamental in the elaboration of a certain philosophical and mystical vocabulary. We argue that Pascal's dialogue with skepticism and rationalism offered a propaedeutic to his religious thought and articulated a religious philosophical grammar resistant to: a) a mystical vocabulary with Neoplatonic roots, b) a pantheistic philosophy of nature, and c) the ontotheological gesture that gave birth to what Pascal called the god of philosophers.
\end{abstract}

Keywords: Pascal; religion; christianity; philosophy; contingency 


\section{Pascal: la religión como experiencia de contingencia y alteridad}

\section{Resumen}

El artículo analiza la interpretación de Pascal del concepto de religión y la configuración anárquica del cristianismo presente en su obra Pensées. A la luz de conceptos centrales en la obra pascual, como equívoco, desproporción y contingencia, y su diálogo con el pensamiento de Descartes y Montaigne, el artículo presenta el rechazo pascual de los conceptos de naturaleza, interioridad y principio, fundamentales en la elaboración de cierto vocabulario. filosófico / teológico y místico. Sostenemos que el diálogo de Pascal con el escepticismo y el racionalismo ofreció una propedéutica a su pensamiento religioso y articuló una gramática filosófica religiosa resistente a a) un vocabulario místico con raíces neoplatónicas, b) una filosofía panteísta de la naturaleza yc) el gesto ontoteológico que dio a luz a lo que Pascal llamó el dios de los filósofos.

Palabras clave: Pascal; religión; Cristiandad; filosofía; contingencia

\section{Equivocidade}

Pascal foi, em tudo que pensou e escreveu, testemunha da profanação moderna da cosmologia filosófica e religiosa dos antigos e arguto observador de uma natureza muda e do universo desprovido de sentido da filosofia e da ciência moderna. Elegendo como interlocutores o ceticismo de Montaigne e o racionalismo de Descartes, Pascal rejeitou a indiferença cética do primeiro e o racionalismo dogmático do segundo, antecipando em dois séculos o niilismo dos modernos diante de uma natureza esvaziada e de um cosmos desprovido de valor moral (KOYRÉ, 1957, p.43). Sob o prisma filosófico dos dois pensadores, Pascal foi um cético e um homem das ciências, e soube colocar sub judice qualquer argumento de autoridade não submetido à observação empírica. As primeiras considerações do seu Prefáce sur le traité du vide nos oferece uma boa imagem do seu lugar na história do pensamento científico e do seu papel na querela entre antigos e modernos. Para o autor do prefácio, "le respect que l'on porte à l'antiquité est aujourd'hui à tel pont, dans les matières où il doit avoir moins de force, que l'on se fait des oracles de toutes ses pensées et des mystères même de ses obscurités" (PASCAL, 1844, p.91). A observação de Pascal em relação ao respeito reservado à antiguidade traduz uma posição que salientou a ausência de qualquer correspondência entre o racionalismo de Galileu e Descartes e a tradição filosófico-teológica aristotélica e/ou neoplatônica. No seu percurso científico e no contexto da elaboração dos Pensées, que é a obra chave para o entendimento da sua trajetória como pensador religioso, Pascal assimilou como nenhum outro 
em seu tempo as consequências da destruição da cosmologia dos antigos e atestou a ausência de qualquer princípio teológico ou filosófico que pudesse estabelecer uma experiência de unidade para o homem no mundo.

Desde muito cedo Pascal tornou-se indiferente aos modelos filosóficos do aristotelismo e resistente às especulações do neoplatonismo, estabelecendo uma criteriologia de pensamento que procurou levar ao esgarçamento os limites do pensamento filosófico e científico através de um confronto com o ceticismo de Montaigne e o racionalismo de Descartes. A criteriologia pascaliana, que nos Pensées é aplicada como um modelo de apologética religiosa do cristianismo, parte de uma renúncia sobre qualquer possibilidade de unidade filosófica ou religiosa da natureza e assume a desproporção e a absoluta contingência da experiência do homem no mundo. O ceticismo e o racionalismo modernos foram dessa forma apresentados como uma espécie de propedêutica ao pensamento religioso e assumiram a impossibilidade de qualquer recuo a um misticismo com raízes neoplatônicas, a uma filosofia panteísta da natureza ou a uma ontoteologia que deu à luz o ídolo metafísico que Pascal nomeou como deus dos filósofos. A natureza fragmentária dos Pensées, avesso a qualquer unidade, pode ser lida como uma combinação entre o atomismo científico do empirismo racionalista e o gesto ensaístico de Montaigne $^{1}$, e nela encontramos a articulação de uma gramática religiosa que se moque de todo o idealismo filosófico ou teológico: "Diversidade. A teologia é uma ciência, mas ao mesmo tempo quantas ciências há? Um homem é um suposto, mas, se a gente o anatomiza, o que passa a ser? A cabeça, o coração, o estômago, as veias, cada veia, cada porção de veia, o sangue, cada humor do sangue" (PASCAL, 2001, frag. 65).

A gramática religiosa que articula os Pensées admite a insignificância de uma ciência teológica na medida em que ela pressupõe que "se há um deus, ele é infinitamente incompreensível, visto que, não tendo nem partes nem limites, não tem nenhum ponto de relação conosco. Somos, pois, incapazes de conhecer quer aquilo que ele é, quer se ele é. Assim sendo, quem ousará empreender a tarefa de resolver essa questão? Não somos nós" (frag. 418). $\mathrm{O}$ argumento de Pascal, que parte de uma criteriologia que reconhece os limites das "luzes naturais", relaciona esses limites empíricos à natureza apofática da religião cristã e à ideia que está no núcleo da sua interpretação do cristianismo: Deus é um Deus absconditus. Na articulação da sua hermenêutica

\footnotetext{
1 "não é em Montaigne, mas em mim que encontro tudo aquilo que nele vejo" (PASCAL, 2001, frag. 689)
} 
da tradição judaico-cristã, Pascal afirma que "é esse o nome” que Deus "dá para si nas escrituras, Deus absconditus" (427), e, lançando os princípios da sua apologética, vincula a condição natural do homem no mundo, privado de toda relação com o divino, com a sua compreensão apofática da religião cristã. Para Pascal, "o que aparece não marca nem uma exclusão total, nem uma presença manifesta da divindade, mas a presença de um Deus que se oculta. Tudo carrega essa característica" (449). Pascal nos apresenta uma leitura singular do cristianismo e o relaciona ao estado de ambiguidade do homem no mundo, "é incompreensível que Deus exista e incompreensível que ele não exista" (809), colocando ao mesmo tempo em suspensão a indiferença cética (Pirrônicos e Montaigne) e o dogmatismo teológico (St. Agostinho) e ontoteológico (Descartes) que se estabeleceram como modelos tradicionais de interpretação da religião. Dirigindo-se aos ateus libertinos, e os colocando no mesmo barco em que navegam os crentes, Pascal considerou que:

Deus existe ou não existe; mas para que lado penderemos? A razão nada pode determinar a esse respeito. Existe um caos infinito que nos separa. Joga-se um jogo na extremidade dessa distância infinita, em que dará cara ou coroa. Que aposta fareis? Pela razão não podeis fazer nem uma coisa nem outra; [...] não recrimineis, então, por falsidade, aqueles que fizeram uma escolha, pois não sabeis nada a respeito [...] Sim, mas é preciso apostar. É inevitável, estais embarcados nessa (418).

No argumento pascaliano subjaz uma desconstrução do vocabulário dogmático do teísmo e do ateísmo, ao mesmo tempo em que renuncia o aparato ontoteológico e conceitual de Descartes que pretendeu certificarse da existência de Deus através do simples conceito: "a razão não pode determinar a esse respeito". Para Pascal, o desemparo cognitivo que embala o movimento daqueles que "fizeram uma escolha" pela religião é o mesmo que acompanha aqueles que se inclinam a rejeitá-la: "não procuremos, portanto, segurança e firmeza; nossa razão está sempre decepcionada pela inconstância das aparências: nada pode fixar o finito entre os dois infinitos que o encerram e fogem dele" (199).

O que a fortuna crítica caracterizou como "visão trágica" (GOLDMANN, 1959) e que distancia Pascal dos seus interlocutores, Descartes, Montaigne e os discípulos de Santo Agostinho em Port Royal, ou seja, racionalismo, ceticismo e dogmatismo teológico, encontra-se cirurgicamente descrito em um dos seus aforismos: "somos incapazes de não 
desejar a verdade e a felicidade e somos incapazes de certeza e felicidade" (401). A distância de uma ataraxia pirrônica e do ceticismo despreocupado de Montaigne vem à luz embalada por um temperamento religioso incapaz de "não desejar a verdade e a felicidade" e de, ao mesmo tempo, constatar que elas são inalcançáveis. A recusa de uma lassidão cética, que não possui como princípio uma busca por valores que transcendam a equivocidade de um mundo no qual "o mal é fácil de praticar, pois existe uma infinidade deles" e "o bem é quase único" (526), fez de Pascal um dos mais sofisticados moralistas modernos. Ao contrário de muitos entre os seus contemporâneos, a observação empírica da natureza e do homem aparece em Pascal na forma de um lamento trágico, pois, acaso alguém teria "a pretensão de nos ter alegrado ao dizer-nos que considera que a nossa alma não é mais do que um pouco de vento e de fumaça, e ainda dizer-nos isso num tom de voz orgulhoso e contente? Seria isso algo a dizer alegremente? E não seria algo a se dizer tristemente, pelo contrário, como a coisa mais triste do mundo?" (427).

Os Pensées se encontram dentro de um arco epistemológico que abrange a tradição cética e o racionalismo cartesiano e possuem, na tematização de elementos do cristianismo, o princípio de articulação de uma antropológica filosófico-religiosa. No fragmento 406, lemos: "temos uma impotência de provar invencível para todo o dogmatismo. Temos uma ideia da verdade invencível para todo o pirronismo". A impotência da razão diante da infinidade de coisas que a ultrapassam (186), a humilhação provocada pela verdade dos conhecimentos naturais, a desproporção do homem com a natureza e a inutilidade desses "títulos tão comuns: Dos princípios das coisas, Dos principios da filosofia, e aos semelhantes e igualmente faustosos" (199) traduzem uma arquitetura da natureza humana que apresenta como desdobramento lógico um niilismo moral. O desprezo de Pascal pela lassidão moral dos céticos e por uma suspensão de juízo sobre a verdade que se entrega sem nenhuma resistência ao relativismo do hábito marca a sua atividade como moralista e pensador religioso. O que afasta Pascal de Montaigne e da tradição cética pirrônica é a "invencível ideia de verdade" que não permite ao moralista ver-se livre das inquietações provocadas pela ambiguidade do mundo. No entanto, para Pascal o ceticismo pirrônico está correto na medida em que ele revela a impotência do dogmatismo e das falsas seguranças derivadas das puissances trompeuses da razão. É nesse contexto que deve ser lida a contundente afirmação de Pascal, "o pirronismo é a verdade" (691). Na criteriologia pascaliana, o pirronismo é a verdade porque ele descreve filosoficamente a 
ambiguidade de um estado no qual "a natureza não oferece nada que não seja matéria de dúvida e de inquietação” (429). É através dessa percepção que o ceticismo aparece como propedêutica ao pensamento religioso e, por isso, no contexto das controvérsias epistemológicas travadas por Pascal, "o pirronismo serve à religião" (659).

\section{Desproporção e experiência mística}

O entendimento de Pascal da religião está atravessado por um olhar que aprendeu a contemplar abismos em silêncio. Não há nada em seu pensamento que não esteja atravessado pelo estado de ambiguidade do homem no mundo. A sua renúncia da ataraxia pirrônica e de uma tranquilidade cética que sustentaria uma postura blasé diante da equivocidade do mundo deu lugar a um aprofundamento filosófico-religioso desta mesma equivocidade. Para Pascal,

qualquer termo em que pensemos em nos agarrar e nos firmar, abala-se, e nos abandona, e, se o seguimos, ele escapa às nossas tentativas de pegá-lo, escorrega e foge com fuga eterna; nada se detém para nós. É o estado que nos é natural e, entretanto, o mais contrário à nossa inclinação. Ardemos de desejo de encontrar uma posição firme e uma última base constante para aí edificar uma torre que se eleve ao infinito, mas todo o nosso alicerce cede e a terra se abre até os abismos" (199).

No espaço da natureza, os movimentos do homem se dirigem apressados ou lentamente, do oco para o vazio, como escreveu o moralista russo que aprendeu a pensar dentro e a partir do subsolo e descobriu que, por mais que se desejasse ou reivindicasse, causa primeira alguma poderia ser encontrada (DOSTOIÉVSKI, 2009). A cada movimento do pensamento, "um abismo novo" (199), não havendo vida interior, natureza e nem mesmo metafísica capaz de aplacar os abismos que se multiplicam ao infinito. Ao recusar os modelos filosóficos que advogaram um princípio metafísico para se pensar o divino, conforme postulados pela causalidade aristotélica ou pela interioridade conceitual de Descartes, Pascal provocou uma desconstrução avant la lettre da metafísica que conferiu uma configuração anárquica à sua hermenêutica do cristianismo: "Fogo. Deus de Abraão, Deus de Isaque, Deus de Jacó. Não dos filósofos e dos sábios" (913). As palavras que abrem o Memorial (PASCAL, 2001, p.370)² traduzem o recuo de Pascal em relação a

2 Pascal, B. Pensamentos. Martins Fontes, São Paulo, 2001, p.370 
uma experiência filosófica ou religiosa que reivindique para si uma ontologia ou um princípio metafísico constituidor da realidade, seja ele nomeado como interioridade, natureza ou mesmo Deus. A anarquia da gramática filosóficoreligiosa pascaliana renuncia tais princípios por pressupor que, cedo ou tarde, "todo o nosso alicerce cede e a terra se abre até os abismos. Não procuremos, portanto, segurança e firmeza”. (199)

Analisados à luz da criteriologia pascaliana, os conceitos de experiência religiosa e de experiência mística ganham um significado sem correlação com as suas formas tradicionais, tais como aparecem na história do pensamento cristão. Sabemos que o esvaziamento do argumento cosmológico ou, como entendeu Kant, cosmoteológico ${ }^{3}$, e a constituição de uma interioridade moderna ofereceram o cenário para o surgimento do vocabulário místico nos séculos XVI e XVII ${ }^{4}$. M. De Certeau demonstrou como a percepção do infinito no interior do homem tornou-se o ponto de partida da reconstrução de uma ordem no universo e o elemento comum entre uma gramática filosófica cartesiana e a linguagem dos espirituais. Para Certeau, "l'expérience des mystiques est analogue à celle des plus audacieux parmi leurs contemporains. De son côté, parti 'comme un homme qui marche seul et dans les ténèbres', Descartes découvrira dans le cogito l'innéité actuelle de l'idée de Dieu" (CERTEAU, 1987, p.52). A resistência de Pascal as puissances trompeuses do sujeito cartesiano são bem conhecidas e entendemos que, no contexto da criteriologia filosófico-religiosa dos Pensées, ela poderia

3 Kant, I. Critica da Raz̧ão Pura. Tradução Manuela Pinto dos Santos. Editora da Fundação Calouste Gulbenkian, Lisboa, 2001. "A teologia transcendental ou pretende derivar a existência do Ser supremo de uma experiência em geral (sem determinar nada de mais preciso acerca do mundo ao qual esta pertence) e denomina-se cosmoteologia, ou pretende conhecer a sua existência através de simples conceitos, sem o recurso à mínima experiência e chama-se ontoteologia". Sétima secção A 632 B 660, p.525.

4 Cf. De Certeau, M. La faiblesse de croire. Éditions du Seuil, 1987. "le "thème" symbolique de Thérèse ne dit plus la structure d'un objet cosmique, mais celle du sujet; il transpose en une anthropologie l'ancienne cosmologie. Le cosmos ( dont le fond est la terre où descende l'influx céleste et d'où s'élève l'âme pour rejoindre l'empyrée) devient microcosme humain: "globe" comme le monde ancien et "cristal" comme la bulle, c'est un monde que chaque sujet constitue à lui seul, dont le centre est "résidence" de Dieu et dont l'environnement est "abîme d'obscurité" [...] La détérioration d'un univers devient pour Thérèse le langage d'un autre univers, celui-là anthropologique. Le désarroi qui dépouillait 1 'homme de son monde et, simultanément, des signes objectifs de Dieu, est précisément pour lui le rendezvous de sa renaissance spirituelle. C'est là que le fidèle trouve le signe de Dieu, certitude désormais établie sur une conscience de soi. Il découvre en lui-même ce qui le transcende et ce qui le fonde dans l'existence. P.50-51 
ser aplicada, talvez de forma menos incisiva, não à experiência religiosa dos espirituais, mas ao que M. Certeau chamou de "le destin prodigieux du mot mystique au XVII siècle" (Ibid, p.52).

As referências ao conceito de experiência mística no conjunto dos Pensées são raras e, no entanto, revelam-se bastante ilustrativas. O nome de Santa Teresa é mencionado três vezes na obra e em todas elas encontramos o que poderíamos nomear, se tal expressão for legitima, como um exercício de desmistificação da experiência mística que resultou da compreensão pascaliana do significado da experiência religiosa. Para Pascal,

O que nos atrapalha quando comparamos o que aconteceu antigamente na igreja ao que acontece hoje é que geralmente se olha Santo Atanásio, Santa Teresa e os outros como coroado de glória e de anos, considerados antes de nós como deuses. Agora que o tempo esclareceu as coisas, isso parece assim, mas no tempo em que era perseguido, esse grande homem santo era um homem que se chamava Atanásio e Santa Teresa uma moça. Elias era um homem como nós e sujeito às mesmas paixões que nós, diz São Pedro, para livrar os cristãos dessa falsa ideia, que nos faz rejeitar os exemplos dos santos como desproporcionais em relação ao nosso estado (598).

O destino prodigioso da palavra mística a que se referiu $M$. Certeau carregou a potência de uma experiência que foi, ao lado do cogito cartesiano, fundadora da modernidade (GUERREIRO, 2007). O excesso da linguagem mística dos espirituais que depreenderam neles mesmos uma transcendência fundadora de interioridade, instaurando com isso uma viragem na espiritualidade cristã, provocou em Pascal um juízo que procurou deslocar estes espirituais do lugar aristocrático no qual estiveram tradicionalmente colocados. A aristocracia espiritual dos místicos é, para Pascal, um equívoco de recepção, pois "esse grande homem santo era um homem que se chamava Atanásio e Santa Teresa uma moça”. Há em Pascal um exercício de linguagem que desejou confrontar o excesso do vocabulário místico com a modéstia proveniente de uma filosofia religiosa que se caracterizou por seu empenho em desenhar os contornos e os limites de uma "science de l'expérience" (CERTEAU, 1987, p.53). O pensamento religioso de Pascal não nega, portanto, a experiência mística in toto, mas sim a sua dimensão de excepcionalidade, e procura circunscrevê-la aos limites tradicionais da experiência religiosa. Nesse sentido, poderíamos afirmar que a experiência religiosa da jovem Teresa não difere qualitativamente em nada da 
modesta conversão de uma camponês de província. As duas experiências se encontrariam mergulhadas na equivocidade e na condição de desproporção absoluta do homem em relação ao infinito. A não participação e a radical separação entre a condição do homem e aquilo que o ultrapassa, os dois infinitos que não permitem uma metafísica e tão pouco uma ciência da experiência, submetem a experiência filosófica e a experiência mística ao insuperável estado de equivocidade e miséria do homem. No aforismo (721), lemos: “o ardor dos santos em buscar a verdade seria inútil se o provável fosse seguro. O temor dos santos que tinham seguido sempre o mais seguro. Santa Teresa tendo seguido sempre o seu confessor".

Um elemento determinante no pensamento filosófico-religioso de Pascal foi a sua rejeição da interioridade como um espaço qualitativo de discernimento e de sentido da realidade. Este ponto é importante pois nos aproxima do seu juízo em relação ao quadro filosófico, científico e religioso no qual encontramos o advento do vocabulário místico. A perda do cosmos, que conforme mostrou M. De Certeau, definiu os quadros mentais dos séculos XVI e XVII e determinou a existência e o objeto de saber de um homem que se viu "forçado a procurar em si mesmo uma certitude e uma regra” (CERTEAU, 1987, p.48), é o princípio que entrelaça a descoberta de uma interioridade filosófica e a linguagem dos espirituais. No fragmento intitulado "filósofos", Pascal considera que

estamos cheios de coisas que nos projetam para fora. O nosso instinto faznos sentir que é preciso buscar a nossa felicidade fora de nós. As nossas paixões nos empurram para fora, mesmo quando os objetos não se oferecem para excitá-las. Os objetos exteriores nos tentam por si mesmos e exercem um apelo sobre nós, ainda que não pensemos neles. E assim não adianta os filósofos dizerem: entrai dentro de vós mesmos, aí encontrareis o vosso bem; não se acredita neles, e aqueles que acreditam são os mais vazios e os mais tolos (143).

O contexto filosófico dos Pensées está atravessado pela filosofia estoica e pelo ceticismo pirrônico e, portanto, demonstra como esses princípios filosóficos estiveram presentes na experiência mística e no pensamento filosófico de Descartes e Montaigne. Para Pascal, “aquilo que os estóicos propõem é tão difícil e tão vão" (144), pois eles dizem, "entrai dentro de vós mesmos, é aí que encontrareis o repouso. E isso não é verdade” (407). A ascese estoica contempla a exterioridade do mundo através de uma experiência 
de si que pressupõe um "eu" que se apresenta, conforme a expressão de Epicteto, através da imagem de um "castelo interior" (BENSUSSAN, 2019, p.19). Este princípio de interioridade marca o estoicismo e não seria equivocado associar a interioridade estoica aos elementos básicos que darão forma à narrativa mística de Santa Teresa. Ao interpretar a experiência mística através das categorias tradicionais da experiência religiosa do cristianismo e colocar a experiência de Santa Teresa dentro da cotidianidade prosaica da fé cristã, Pascal sinaliza que a interioridade, entendida como o centro da doutrina estoica do bem, não poderia ser interpretada como o princípio ou locus de discernimento da verdade e da realidade. O eu para pascal, e da mesma maneira para Montaigne, mostra-se através das suas "qualidades postiças", e não carrega nenhuma substancialidade que possa ser equiparada à abstração da imagem estoica ${ }^{5}$.

Não seria equivocado considerar que há em Pascal uma resistência ao cultivo de uma prática espiritual que pressuponha a noção estoica de eu e, o que é decorrente disso, a mistificação de uma interioridade que pudesse ser por si mesma capaz de configurar e imprimir substância no mundo. A ideia de interioridade, tal como a noção estoica da natureza, caso se considere "aonde nos levam os conhecimentos naturais" (199), aparece em Pascal como realidades fictícias que possibilitam uma prática espiritual naïf: "aqueles que acreditam são os mais vazios e os mais tolos" (143). Consciente do seu estado de desproporção em relação à natureza e, portanto, privado de qualquer ontologia, Pascal reconhece no eu estoico uma abstração e nos exercícios espirituais da ascese antiga ou cristã, caso partilhem da mesma ideia de interioridade estoica, uma atividade prosaica que poderia ser classificada como um divertissement.

5 No seu vastamente citado fragmento sobre o eu, Pascal considera: "o que é o eu? Um homem que se põe na janela para ver as pessoas que passam; se passo por ali, posso dizer que ele se pôs na janela para me ver? Não; porque ele não está pensando em mim particularmente; mas quem ama alguém por causa de sua beleza, ama mesmo? Não, porque as bexigas, que matara a beleza sem matar a pessoa, fará com que ele não a ame mais. E se amam pelo meu juízo, por minha memória, amam-me mesmo? A mim? Não, pois posso perder essas qualidades sem perder-me a mim mesmo. Onde está então esse $e u$, se não está no corpo, nem na alma? E como amar o corpo ou a alma senão por essas qualidades que não são o que fazem o eu, pois que são perecíveis? porque alguém amaria a substância da alma de uma pessoa, abstratamente, e algumas qualidades nela existentes? Isso não é possível, e seria injusto. Portanto nunca se ama ninguém, mas somente qualidades. Não se zombe mais então daqueles que se fazem honrar por cargos e ofícios, pois não se ama ninguém a não ser por qualidades postiças. Não é em Montaigne, mas em mim que encontro tudo que nele vejo. (688) 
A resistência de Pascal ao estoicismo nos ajuda a compreender o seu juízo sobre a experiência mística e lança luzes sobre uma criteriologia filosófico-religiosa que assume a condição de um homem "incapaz de ver o nada de onde foi tirado e o infinito em que é engolido" (199). Os espaços de mediação [e meditação] tradicionais, tais como aparecem no estoicismo e em práticas espirituais de caráter místico e ascético, são rejeitados em nome de uma hermenêutica do cristianismo que pressupõe a presença e a ausência de um dieu caché. A religião cristã assume, segundo Pascal, a equivocidade do mundo, e é este o sentido que torna os Pensées uma apologética do cristianismo. Para o filosofo de Port Royal, "sendo Deus assim escondido, toda religião que não diz que Deus é escondido não é verdadeira, e toda religião que não indica a razão disso não é instrutiva. A nossa faz tudo isso. Vere tu es deus absconditus" (242). A expressão deus absconditus, retirada por Pascal da tradição profética do livro de Isaias, traduz os elementos básicos do monoteísmo judaico, o qual pressupõe uma completa dessacralização da ideia de natureza e a absoluta transcendência da divindade. Essa apropriação deu forma a uma compreensão da religião e da experiência religiosa que pressupôs, tal como encontramos no judaísmo bíblico, o caráter não místico da experiência com o divino e a radical separação entre Deus e o homeḿ.

\section{Religião, contingência e alteridade}

No pensamento de Pasca desenha-se uma arquitetura filosóficoreligiosa desprovida de princípios. Resistente a toda ordem que assumiu uma via mística com raízes neoplatônicas, uma filosofia e/ou teologia da natureza ou mesmo uma ontoteologia que sustentou a existência do que ele mesmo nomeou como deus dos filósofos, Pascal deu à luz ao que poderíamos chamar, seguindo as intuições de Jean Luc-Nancy, de uma configuração anárquica do cristianismo. Para Nancy,

Ce n'est pas un hasard si en plein essor de la rationalité moderne, Pascal éprouve si violemment, dans son "Memorial", la nécessité de disjoindre sans réserve le Dieu "des philosophes et des savants" du "DIEU d'Abraham, d'Isaac et de Jacob, DIEU de Jésus-Christ”. Cette disjonction et la contrariété ou la contradiction qui en resulte sont logées au coeur de l'athéisme, très exactement à l'endroit où le príncipe même du príncipe s'effondre de lui même et, dans cet effondrement, signale la possibilite, voire l'exigence et l'appel d'une tout autre configuration anarchique (NANCY, 2005, p.38-39).

Cf. Gutmann, J. A filosofia do Judaísmo. São Paulo: Perspectiva, 2017. Conforme o entendimento de Pascal, "os verdadeiros judeus e os verdadeiros cristãos não tem senão uma mesma religião” (453) 
O princípio do princípio, para usarmos a expressão de Nancy, que entrou em colapso no pensamento pascaliano atesta a inexistência de qualquer experiência de mediação ou unificação, para nos aproximarmos de uma gramatica mística, entre o estado de equivocidade do homem e aquilo que o ultrapassa. A consciência de despedaçamento da natureza e do ordenamento fictício do eu resultou em Pascal em um esvaziamento da existência que, privada de qualquer causalidade e identidade, assumiu uma relação com a exterioridade de absoluta alteridade e contingência. É sob este prisma antimetafísico que deve ser lido o lamento pascaliano em relação à "desproporção do homem": "o silêncio desses espaços infinitos me apavora" (201). Pascal enuncia uma condição de equivocidade que distancia o seu cristianismo das formulações metafisicas tradicionais, como encontramos, por exemplo, naquilo que Jean-Luc Nancy nomeou como "estoicismo-cristão", o qual encontrou no nome de Deus uma forma de nomear o princípio de uma totalidade pressuposta, fundada na unidade e na necessidade (NANCY, 2005, p. 35). A perda da unidade cosmoteológica do mundo e a recusa, por Pascal, de uma vida interior, entendida como experiência filosófica ou mística, que fosse capaz de dar forma, ascética ou conceitualmente, a uma outra experiência de unidade da existência, ofereceram o cenário para a formulação pascaliana de um cristianismo trágico. No aforismo (429), lemos:

Aí está o que vejo e o que me perturba. Olho para todos os lados e por toda parte só vejo escuridão. A natureza não me oferece nada que não seja matéria de dúvida e de inquietação. Se aí não visse nada que fosse marca da Divindade, eu me determinaria pela negativa; se visse por toda parte as marcas de um Criador, descansaria em paz na minha fé. Mas vendo demais para negar e muito pouco para me certificar, fico num estado lastimável em que mil vezes desejei que, se um Deus a sustenta, ela marcasse isso sem equívoco; e, se as marcas que ela apresenta são enganosas, que ela as suprimisse completamente; que dissesse tudo ou nada, a fim de que eu visse que partido devo tomar. Ao passo que no estado em que estou, ignorando o que sou e o que devo fazer, não conheço nem a minha condição, nem o meu dever. Meu coração tende inteiro a conhecer onde está o verdadeiro bem, para segui-lo; nada me seria demasiado caro pela eternidade. Tenho inveja daqueles que vejo na fé viver com tanta negligência, e que usam tão mal um dom de que me parece que eu faria um uso tão diferente.

Pascal talvez tenha sido o primeiro pensador moderno a propor, através da sua oposição entre o deus dos filósofos e o deus de Abraão, uma 
experiência do cristianismo avessa aos princípios da metafísica. Partindo de um ceticismo que renunciou aos excessos da subjetividade, os quais se manifestam através das puissances trompeuses da razão, e àqueles presentes numa espiritualidade naîf de mistificação da natureza ou da vida interior, Pascal formulou um conceito de experiência religiosa contrária a qualquer princípio e imprimiu um novo significado, à luz da experiência moderna, ao conceito de fé que encontramos no interior da tradição judaica e cristã. A observação de Pascal sobre o fato de não haver nada na natureza que não seja matéria de dúvida e inquietação, a sua completa ignorância de si e do que se deve fazer, apresentaram o ponto de partida pascaliano, que foi o seu próprio niilismo (nibi), para uma hermenêutica do cristianismo. O abismo que se interpôs entre o pensamento de Pascal e a metafísica clássica, ou, conforme a expressão de J. L. Nancy, "a história de "Deus" - do Deus do Ocidente" (NANCY, 2005, p.35), compreendida à luz da tradição aristotélica e da ideia de alma e bem supremo do platonismo e neoplatonismo, explica também a sua distância e o seu juízo crítico em relação a uma hermenêutica dogmática do cristianismo. As provas da existência de Deus que encontramos em obras como De Libero arbitrio e De vera religione, de Santo Agostinho, que constituíram uma tradição dogmática que se estendeu ao Proslogion de Santo Anselmo (MARTINS, 2009) e atravessou o imaginário religioso de Port Royal, foram colocadas em suspensão através da dúvida cética reivindicada por este enfant terrible do jansenismo que foi Pascal'.

Entendemos que a apologética do cristianismo presente no interior dos Pensées deve ser interpretada como um movimento avant la lettre de desconstrução da metafísica que, ao retornar à gramática do monoteísmo judaico, soube articular uma experiência do cristianismo privada de qualquer possibilidade de articulação dogmática. Para Pascal, não existem certezas no interior do discurso religioso e, da mesma forma, existe um grau radical de incertitude que determina os limites do discurso racional. Nesse sentido, não fosse a estridente reinvindicação de verdade proveniente do temperamento religioso de Pascal, a ataraxia pirrônica acompanhada dos divertissements que oferecem à existência experiências de enriquecimentos numerosas, seria um caminho filosófico digno e a religião uma mera excentricidade. No entanto,

"Se há um deus, ele é infinitamente incompreensível, visto que, não tendo nem partes nem limites, não tem nenhum ponto de relação conosco. Somos, pois, incapazes de conhecer quer aquilo que ele é, quer se ele é. Assim sendo, quem ousará empreender a tarefa de resolver essa questão? Não somos nós" (418). 
em Pascal, "o coração tende inteiro a conhecer onde está o verdadeiro bem”, e é este o sentimento que provoca o seu desprezo pelo niilismo indiferente dos pirrônicos. Mas, ao rejeitar o dogmatismo dos discípulos de Santo Agostinho, por entender que, por mais que o coração busque a verdade "só encontramos em nós incerteza” (401-437), Pascal inaugura uma tematização da experiência religiosa que se articulou a partir da contingência insuperável da existência e da absoluta alteridade e exterioridade de uma realidade que escapa ao homem.

Se não se devesse fazer nada a não ser pelo certo, não se devia fazer nada pela religião, pois ela não é certa. Mas quanta coisa se faz pelo incerto, as viagens por mar, as batalhas. Digo pois que não se deveria fazer absolutamente nada, pois nada é certo. E que existe mais certeza na religião do que na possibilidade de vermos o dia de amanha. Porque não é certo que vejamos o amanhã, mas é certamente possível que não o vejamos. Não se pode dizer o mesmo da religião. Não é certo que ela seja, mas quem ousará dizer que é certamente possível que ela não seja? Ora, quando se trabalha pelo amanhã e pelo incerto, age-se com razão, pois deve-se trabalhar pelo incerto pela regra dos partidos que está demonstrada. Santo Agostinho viu que se trabalha pelo incerto no mar, na batalha etc. - mas não viu a regra dos partidos que demonstra que se deve fazê-lo. Montaigne viu que as pessoas se ofendem com um espirito coxo e que o costume tudo pode, mas não viu a razão desse efeito (577).

O argumento de Pascal censura em Agostinho o fato de este não ter levado às últimas consequências o caráter fundamental da incerteza na existência humana (GOLDMANN, p.321) e alimentado um dogmatismo que conferiu à experiência religiosa as certitudes positivas da razão e da tradição. Contrariando a fortuna crítica agostiniana que encontrou na razão e na autoridade dos apóstolos um meio de certificação da religião, Pascal reivindica que, da mesma maneira em que, nas batalhas e nas viagens o homem se vê diante do incerto, a religião, por sua vez, também não é certa. Por ignorar a equivocidade radical do estado que nos é natural, "ardemos de desejo de encontrar uma posição firme", e por isso tanto a filosofia como a religião encontram-se diante do equívoco de "edificar uma torre que se eleve ao infinito", que, mais cedo ou mais tarde, revelar-se-á um abismo. Para Pascal, o mesmo movimento do espírito que estrutura as certezas teístas da religião é o que oferece os fundamentos dogmáticos de um ateísmo que procura negá-la. Mas, como argumenta Pascal, "quem ousará dizer que é certamente possível que ela - a religião - não seja?”. A sofisticação da reflexão de Pascal quer 
demonstrar a similaridade entre duas posturas dogmáticas que se imaginam capazes de um movimento de apropriação de um real que as ultrapassa. No fragmento (157) Pascal considera: "ateísmo marca de força de espírito, mas só até certo ponto". Pois, no horizonte pascaliano, não é completamente certo que a exterioridade do mundo nos apresente o nada, ao invés de algo, como também não é "perfeitamente claro que a alma seja material" (166). $\mathrm{O}$ argumento de Pascal encontra-se implícita e explicitamente presente na filosofia da religião contemporânea que procurou fazer um contraponto à ingenuidade dogmática e, muitas vezes vulgar, do ateísmo moderno. Conceitos como o de absenteísmo (absentheísme), utilizado por Jean-Luc Nancy para se opor ao conceito de ateísmo (NANCY, p.32), ou anatheism (anateísmo), como propôs Richard Kearney, a fim de superar a oposição entre um teísmo dogmático e o ateísmo (KEARNEY, 2010), aproximam-se das intuições de Pascal e da sua hermenêutica do cristianismo.

O movimento pascaliano de retirada do cristianismo da metafísica teve como consequência uma desordem que tornou inoperante os movimentos doadores de sentido provenientes de uma experiência filosófica e/ou mística que pressupõem, em suas especificidades, um contato imediato com o divino (LAUX, 2005, p.77). As afinidades eletivas de Pascal com o judaísmo são, nesse sentido, mais que evidentes, e o adágio de Isaias, Deus absconditus, que também se constituiu como princípio de uma inteligência filosófica judaica, Franz Rosenzweig e Emmanuel Levinás, por exemplo, traduziu uma filosofia religiosa que reforçou a desproporção entre o homem e o divino. Dessa forma, a dessacralização do mundo imposta pelo monoteísmo e a transcendência absoluta do Deus judaico, que levou Schelling a perceber a simbiose entre monoteísmo e ateísmo (NANCY, p.27), estão pressupostas no argumento pascaliano e devem ser interpretadas como parte da sua gramática religiosa. Para Pascal, não há nada na fisicalidade do mundo e na interioridade do homem que possibilite uma experiência de unidade e/ou participação do homem na natureza divina. A desordem pascaliana, princípio fundamental da ordem da concupiscência que é o estado natural do homem, pressupõe uma physis sem ontologia e uma psicologia desamparada de toda exterioridade metafísica. O conceito pascaliano de desproporção revela a não causalidade pressuposta por um princípio, entendido como origem, e transforma a ideia de infinito, antes um "nome divino e determinação privilegiada para Deus", em um "índice múltiplo sem fim da incomensurabilidade dos elementos dispersos” (MARION apud PONDÉ, 2001, p.39). 
A desconfiança de Pascal da metafísica e a sua atividade como pensador religioso consagraram na modernidade e no interior do cristianismo a oposição clássica entre Jerusalém e Atenas. Há uma iconoclastia filosóficoreligiosa em seu pensamento que apontou um arsenal crítico em direção a: i) uma filosofia e/ou mística que pressupõe a identificação da alma com um nous divino de tradição platônica e neoplatônica, ii) uma filosofia da natureza naïf que reivindica uma proporção e/ou identidade entre homem e natureza e, por fim, iii) uma espiritualidade ou mística do cristianismo que propõe uma analogia entre homem e Deus e estabelece algo como uma comprehensio ou cognitio do divino. O cristianismo de Pascal, nesse sentido, organizou-se para fora da gramática do helenismo, fundamento e constituição metafísica do deus da filosofia, e aproximou-se de uma gramática do judaísmo e de uma filosofia religiosa que se desfez de todo princípio de causalidade e identidade e deu voz à contingencia absoluta do homem e à alteridade radical da verdade e do bem: "vere tu es deus absconditus".

Os Pensées, de Blaise Pascal, devem ser lidos, contra a naivité das práticas espirituais contemporâneas, como um breviário moderno.

\section{Referências}

BENSUSSAN, G. Être heureux? Ce qui dépend de nous et ce qui n’en dépend pas. Éditions Mimesis/Philosophie et Societé. N.11. Collection dirigée par Yves Charles Zarka. Paris, 2019.

DE CERTEAU, M. La faiblesse de croire. Éditions du Seuil, 1987

DOSTOIÉVSKI, F. Memórias do Subsolo. Ed. 34, 2009.

GUERREIRO, E. Teologia negativa e Theodor Adorno. A secularização da mística na arte moderna. Tese de Doutorado. http://www.posciencialit.letras.ufrj.br/images/ Posciencialit/td/2007/21-eduardoguerreiro_teologianegativa.pdf. Acesso 28 de junho de 2020.

GOLDMANN, L. Le Dieu Chaché. Étude sur la vision tragique dans les Pensées de Pascal e dans le théatre de Racine. Éditions Gallimard, 1959.

KEARNEY, R. Anatheism: Returning to God after God. New York: Columbia University Press, 2010.

KOYRÉ, Alexandre. From the closed world to the infinite universe. Baltimore, Johns Hopkins Press, 1957.

LAUX, Henri. Qu'est-ce que la mystique?, In. Capelle, Philippe (ed). Expérience Philosophique et Expérience mystique, Paris, 2004.

MARTINS, Maria Manuela Brito. A prova da existência de Deus em Santo Agostinho (De Libero Arbitrio) e em Santo Anselmo (Proslogion). https://repositorio.ul.pt/ 
bitstream/10451/24169/1/Philosophica\%2034_5_MManuelaBritoMartins.pdf

NANCY, J L. La Déclosion (Déconstrution du christianisme,1). Paris: Galilée 2005,

PASCAL, B. Préface sur le traité du vide. In. Pensées, fragments et lettres de Blaise Pascal. Tome premier. Paris, Andrieux, Éditeur, 1844.

PASCAL, B. Pensamentos. Martins Fontes, São Paulo, 2001.

PONDÉ, L F. O homem insuficiente. Coleção Ensaios de Cultura. São Paulo: Edusp, 2001.

Submetido em: 1-7-2020

Aceito em: 27-11-2020 